\title{
Inter- and intraspecific genetic and morphological variation in a sibling pair of carabid species Hilde Dhuyvetter*1, Jean-Pierre Maelfait ${ }^{2}$ and Konjev Desender ${ }^{1}$
} Address: ${ }^{1}$ Entomology Department, Royal Belgian Institute of Natural Sciences, Vautierstreet 29, Brussels, Belgium and ${ }^{2}$ Instituut voor natuur- en
bosonderzoek, Brussels, Belgium

Email: Hilde Dhuyvetter* - hilde.dhuyvetter@naturalsciences.be; Jean-Pierre Maelfait - jeanpierre.maelfait@inbo.be; Konjev Desender - konjev.desender@naturalsciences.be

* Corresponding author

Published: 24 April 2007

Saline Systems 2007, 3:4 doi:10.1186/1746-1448-3-4

This article is available from: http://www.salinesystems.org/content/3/I/4

(C) 2007 Dhuyvetter et al; licensee BioMed Central Ltd.

This is an Open Access article distributed under the terms of the Creative Commons Attribution License (http://creativecommons.org/licenses/by/2.0), which permits unrestricted use, distribution, and reproduction in any medium, provided the original work is properly cited.
Received: 24 January 2007

Accepted: 24 April 2007

\begin{abstract}
Background: Pogonus littoralis and Pogonus chalceus are very close related species with quite different ecological preferences within salt marshes. We study the evolutionary processes in and between these presumably young species. Therefore, we compare the variation in ecologically relevant characters and the genetic variation within one of the species (intraspecific differentiation) with the variation of the two types of characters between the two species (interspecific variation). Data are compared between two independent sets of populations, one set at a small geographical scale (the ecologically diverse Guérande area in France) and the other set at a AtlanticMediterranean scale.

Results: Body and relative wing size and IDHI allozyme data show that the intraspecific variation in $P$. chalceus is high and in the same range as the interspecific variation ( $P$. chalceus versus $P$. littoralis). Based on neutral markers (other allozymes and mitochondrial DNA) on the other hand, the intraspecific variation in $P$. chalceus is much lower in comparison to the interspecific variation.

Conclusion: The different ecotypes in the highly polytypic species $P$. chalceus are as highly differentiated in ecological characters as true species, but are not recognised as such by screening neutral DNA polymorphisms. This can be interpreted as a case of ongoing speciation driven by natural selection adapting each ecotype to its respective ecological niche. The same ecological process can be recognised in the differentiation between the two sister species, where en plus reproductive isolation between the two gene pools occurred, allowing independent drift and mutation accumulation in neutral genetic characters.
\end{abstract}

\section{Background}

Pogonus chalceus is a wing polymorphic beetle with extremely variable wing size from short to completely developed wings, with all possible intermediates [1]. A recent study presented population genetic results on $P$. chalceus (Marsham, 1802) beetles from the Guérande saltfields on the French Atlantic coast, based on allozymes and microsatellites, as well as results on wing and body size [2]. In the unique man made Guérande salt-fields, two contrasting habitat types are found mixed on a microscale in hundreds of replicates (sea canal versus salt extraction ponds). Body, relative wing size and IDH1 allozyme alleles are strongly divergent between these two contrasting microhabitats; divergent selection led to two clearly 
distinguishable ecotypes, respectively adapted to canal and pond habitat. Comparisons between the Guérande region (microscale) and populations along the Atlantic coast (macroscale) confirmed the generality of the hypothesis regarding ecological processes responsible for this differentiation: habitat stability [2]. The Guérande ecotypes are also slightly differentiated based on neutral molecular markers (microsatellites and allozymes), suggesting that partial barriers to gene flow between the two ecotypes are present. Previous work on a wide range of taxa has demonstrated that strong natural selection can lead to divergence in spite of gene flow [3-7]. Our Guérande results can therefore be interpreted as a case of ongoing speciation driven by natural selection adapting each ecotype to its respective ecological niche, i.e. species in status nascenti (see also $[8,9]$ ).

In the same Guérande region and along the European Atlantic and Mediterranean coast, another Pogonus species, $P$. littoralis (Duftschmid, 1812) lives in a third kind of microhabitat: unvegetated, temporary dry salt marsh ponds or creeks, where it lives between cracks in humid sea clay. This species is, in contrast to $P$. chalceus, constantly macropterous, always with maximally developed wings and functional flight musculature [10]. The beetle is highly mobile because it regularly has to move between temporarily dry salt marsh ponds and creeks during its life cycle. Both species can be hardly distinguished by external morphology (for example large individuals of $P$. chalceus versus small $P$. littoralis) but have clearly distinguishable genitalia.

The data in this article are to some extent compiled from previous works $[2,11,12]$. Nevertheless, the novelty of this study lies in the fact for the first time the two carabid sister species are analyzed jointly allowing for valuable comparisons to be made. In this study, we will first compare the two ecotypes of Pogonus chalceus with the closely related species, Pogonus littoralis at a microscale (Guérande region). Therefore, we will use population data on wing and body size, IDH1 allozyme polymorphism as well as apparently neutral markers (other allozymes and mtDNA). We will also test if the microscale results are valid at a larger scale across Europe by means of an independent data set of different populations of both Pogonus species. In all of these cases, we will evaluate the contribution of intra population, inter population, inter ecotype and interspecific variation to the total variance.

\section{Results \\ Body size}

Fig. 1 shows male body size for both $P$. chalceus ecotypes and for the P. littoralis populations in the Guérande region [see also additional file 1]. Mean body size for the pond populations is small (3.56; range: 2.9-4.2), intermediate for the canal populations $(4.08 ; 3.4-4.6)$ and high for the P. littoralis populations (4.69; range: 3.9-5.1). Body size values for the females show a similar pattern but are always larger than male body sizes. Mean female body size is 3.91 for the canal populations (range: 3.4-4.3), 4.52 for the pond populations (range: 3.4-5.0) and 4.89 for the P. littoralis populations (range: 4.3-5.3).

Fig. 1 also shows male and female body sizes for the $P$. chalceus ecological groups and for the P. littoralis populations on a European scale [see also additional file 2]. Mean male body size is small for the stable (3.68; range: 3.2-4.3) and intermediate $P$. chalceus populations (3.68; range 3-4.3), somewhat higher for the temporary populations (mean: 3.92; range: $3.4-4.6$ ) and high for the P. littoralis (mean: 4.32; range: 3.6-4.8) ones. Body size values of females show again a similar pattern and are always larger than male body sizes. Mean female body size is 4.04 for the stable P. chalceus populations (range: 3.2 to 4.6 ) compared to 4.11 for the intermediate populations (range: 3.1 to 4.7 ) and 4.3 for the temporary $P$. chalceus populations (range: 3.4 to 4.8 ) and 4.6 for the P. littoralis populations $(4.1-5.2)$.

In the Guérande region and considering the two species (nested design ANOVA; six P. chalceus populations (canals and ponds pooled) versus three P. littoralis populations, the major part of variance (based on body size) is found among species (Table $1 ; 74.24 \%$ for males and $51.96 \%$ for females). If we consider three groups (three canal populations (P. chalceus), three pond populations (P. chalceus) and three $P$. littoralis populations, the major part of variance is even more pronouncedly found among groups ( $84.96 \%$ for males and $72.08 \%$ for females). Variance among populations within groups considering three groups instead of two drops from 17.5 to $2.35 \%$ for males and from 29.57 to $4.28 \%$ for females. This indicates that this variance was almost completely due to the differences in body size between populations of $P$. chalceus from different microhabitats. All variance components are statistically significant.

On a European scale and considering the two species (25 $P$. chalceus populations versus six $P$. littoralis), the major part of variance (based on body size) is found among species (Table $1 ; 68.37 \%$ for males and $48.37 \%$ for females). If we consider four ecological groups (14 temporary $(P$. chalceus), five intermediate ( $P$. chalceus), six stable ( $P$. chalceus) and five $P$. littoralis), the variance among groups drops (49.39\% for males and $33.87 \%$ for females) and the variance within populations augments $(45.62 \%$ for males and $58.53 \%$ for females). Variance among populations within groups considering four groups instead of two drops a little from 10.13 to $5 \%$ for males and from 12.29 

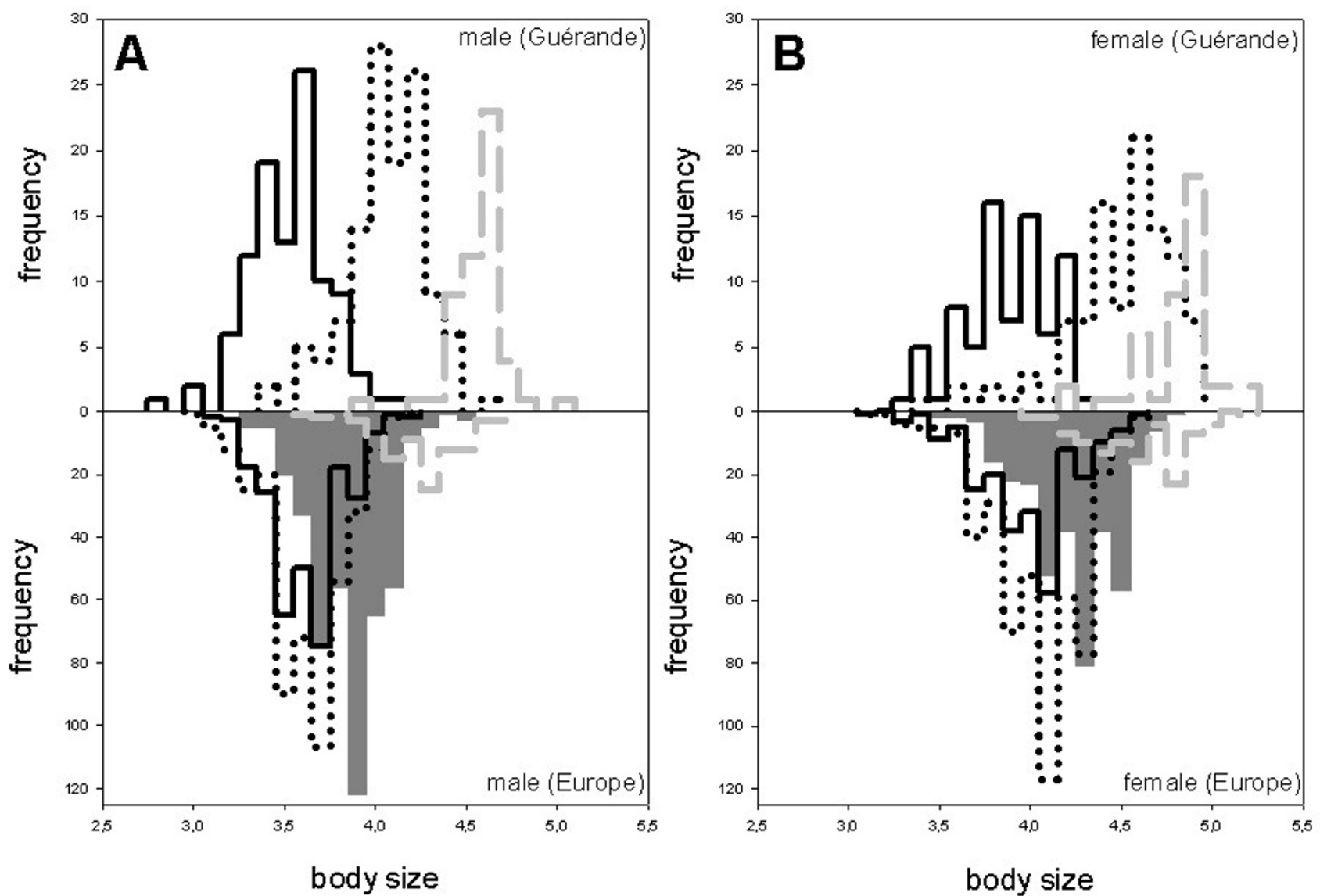

Figure I

Male (part A) and female (part B) body size frequency distributions. In the upper part of A and B: Guérande canal populations (black solid line; Pogonus chalceus), pond populations (black dotted line; Pogonus chalceus) and Pogonus littoralis populations (gray dashed line). In the lower part of A and B: European stable populations ( $P$. chalceus; black solid line), intermediate populations ( $P$. chalceus; black dotted line), temporary Atlantic and Mediterranean populations (gray filled; $P$. chalceus) and Pogonus littoralis populations (gray dashed line). Figure legend text.

to $7.61 \%$ for females. All variance components are statistically significant.

\section{Relative wing size}

Fig. 2 shows male and female relative wing sizes for both $P$. chalceus microhabitats and for the P. littoralis populations in the Guérande region [see also additional file 1]. Mean male relative wing size for the canal populations is small (28.19; range: $20-35 \%$ ), intermediate for the ponds (mean: 64.24 ; range: $25-82.5 \%$ ) and high for the P. littoralis populations (mean: 103.59; range: 92.5-112.5\%). Relative wing size values of females show a similar pattern and are not larger than male relative wing sizes. Mean female relative wing size for the canals is 26.93 (range: 17.5-32.5\%), 62.31 for the ponds (range: 25-80\%) and 103.04 for the $P$. littoralis populations (range: 92.5$110 \%)$.
Fig. 2 also shows male and female relative wing size in ecological groups of $P$. chalceus and of $P$. littoralis populations on a European scale [see also additional file 2]. Mean male relative wing size is small for the populations of the old, highly stable salt marsh areas (35.28; range: $22.5-62.5 \%$ ), some higher for the populations of the salt marshes of intermediate stability (mean: 51.07; range: 25-85\%), higher for the populations of the small, unstable areas (mean: 82.23 , range: $27.5-105 \%$ ) and very high for the $P$. littoralis populations (mean: 106.16; range: 90$112.5 \%)$. Relative wing size values of females show a similar pattern and are not larger or smaller than male relative wing sizes. Mean female relative wing size for the stable populations is 33.43 (range: $20-82.5 \%$ ) compared to 49.91 for the populations of intermediate stability situations (range: $25-85 \%$ ), 80.41 for the temporary populations of the highly unstable salt marshes (range: 40- 
Table I: Analysis of variance (nested design ANOVA) based on male or female body size in two regions: Guérande microscale and Europe macroscale

\begin{tabular}{|c|c|c|c|c|}
\hline region & groups & source of variation & $\%$ var male & $\%$ var female \\
\hline \multirow[t]{6}{*}{ Guérande } & P. chalceus/P. littoralis & among groups & 74.24 & 51.96 \\
\hline & & among populations within groups & 17.50 & 29.57 \\
\hline & & within populations & 8.26 & 18.47 \\
\hline & ponds/canals/P. littoralis & among groups & 84.96 & 72.08 \\
\hline & & among populations within groups & 2.35 & 4.28 \\
\hline & & within populations & 12.69 & 23.63 \\
\hline \multirow[t]{6}{*}{ Europe } & P. chalceus/P. littoralis & among groups & 68.37 & 48.37 \\
\hline & & among populations within groups & 10.13 & 12.29 \\
\hline & & within populations & 21.51 & 39.35 \\
\hline & stable/intermediate/temporary/P. littoralis & among groups & 49.39 & 33.87 \\
\hline & & among populations within groups & 5.00 & 7.61 \\
\hline & & within populations & 45.62 & 58.53 \\
\hline
\end{tabular}

97.5\%) and 107 for the P. littoralis populations (range: $92.5-115 \%)$.

In the Guérande region and considering the two species (nested design ANOVA; six P. chalceus populations (canals and ponds pooled) and three $P$. littoralis populations), the major part of variance (based on relative wing size) is found among species (Table 2; 78.84\% for males and $80.37 \%$ for females). If we consider three groups (three canal populations ( $P$. chalceus), three pond populations (P. chalceus) and three P. littoralis populations), the major part of variance is even more clearly found among groups (95.48\% for males and $93.92 \%$ for females). Variance among populations within groups considering three groups instead of two drops from 18.64 to $0.64 \%$ for males and from 16.21 to $0.8 \%$ for females. This indicates that this variance is almost completely due to the differences in relative wing size between populations of $P$. chalceus from different microhabitats. All variance components are statistically significant.

On a European scale and considering the two species (25 $P$. chalceus populations versus six $P$. littoralis populations), the major part of variance (based on relative wing size) is found among species (Table 2; 57.61\% for males and $60.16 \%$ for females). If we consider four ecological groups (14 temporary $(P$. chalceus), five intermediate ( $P$. chalceus), six stable (P. chalceus) and six P. littoralis populations), the major part of variance is again even more pronounced among groups $(82.22 \%$ for males and $82.58 \%$ for females). Variance among populations within groups considering four groups instead of two drops from 36.11 to $6.34 \%$ for males and from 32.8 to $6.89 \%$ for females. This indicates that this variance is again almost completely due to the differences in relative wing size between populations of $P$. chalceus from different ecological or salt marsh area stability groups. All variance components are statistically significant.

\section{IDHI allozyme marker}

In Guérande, both Idh1-2 and Idh1-4 alleles are frequent in ponds, whereas canals are nearly fixed at Idh1-4 (Fig. 3A) [see also additional file 1]. P. littoralis populations are fixed at the Idh1-6 allele. Allele Idh1-1, Idh1-3, and Idh1-5 are very rare in $P$. chalceus and therefore not shown in Figure 4. Considering the two species (AMOVA; six P. chalceus populations (canals and ponds pooled) and three $P$. littoralis), the major part of variance (based on IDH1) is found among groups (Table 3; 61.93\%). If we consider three groups (three canal populations ( $P$. chalceus), three pond populations (P. chalceus) and three P. littoralis populations, the major part of variance is still found among groups (64.25\%). Variance among populations within groups considering three groups instead of two drops from 11.49 to $0.1 \%$. This indicates that this variance is almost completely due to differences in IDH1 between populations of $P$. chalceus from different microhabitats. All variance components are statistically significant.

At a European scale, both Idh1-2 and Idh1-4 alleles are frequent in the intermediate stability populations, whereas the temporary populations are nearly fixed at the Idh1-2 allele and the stable populations at the Idh1-4 allele (Fig. 3B) [see also additional file 2]. P. littoralis populations are fixed at the Idh1-6 allele. Considering two groups (25 P. chalceus populations versus six P. littoralis populations, the major part of variance (based on IDH1) is found among groups (Table $3 ; 62.29 \%$ ). If we consider four ecological groups (14 temporary ( $\mathrm{P}$. chalceus), five intermediately stable (P. chalceus), six highly stable (P. chalceus) and six P. littoralis populations, the major part of variance is somewhat lower but is still found among groups $(53.26 \%)$. Variance among populations within groups, considering four groups instead of two, drops from 12.26 to $2.07 \%$. This indicates that this variance is almost completely due to differences in IDH1 between populations of $\mathrm{P}$. chalceus from different ecological 

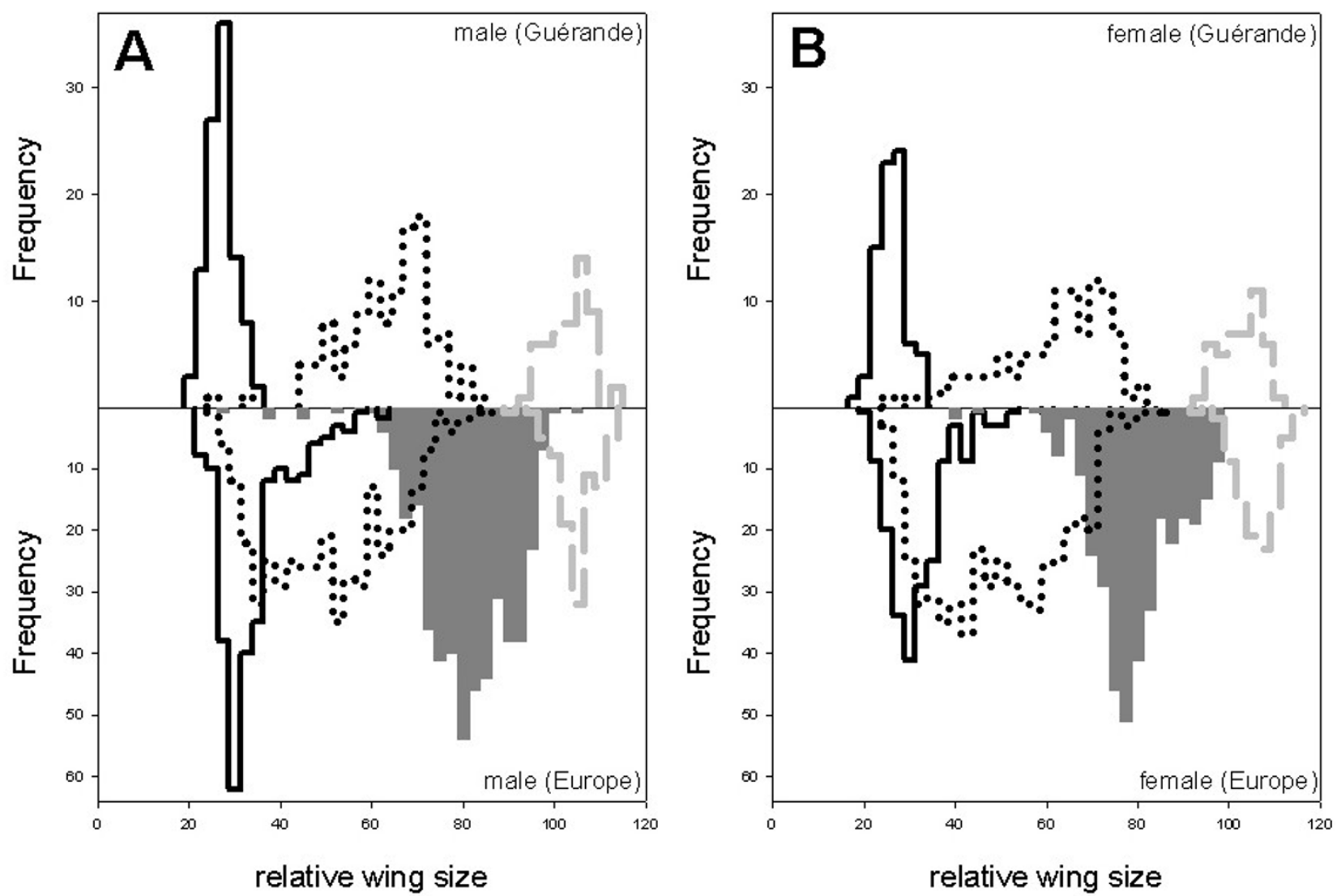

Figure 2

Male (part A) and female (part B) relative wing size frequency distributions. In the upper part of $A$ and $B$ : Guérande canal populations (black solid line; Pogonus chalceus), pond populations (black dotted line; Pogonus chalceus) and Pogonus littoralis populations (gray dashed line). In the lower part of A and B: European stable populations ( $P$. chalceus; black solid line), intermediate populations ( $P$. chalceus; black dotted line), temporary Atlantic and Mediterranean populations (gray filled; $P$. chalceus) and Pogonus littoralis populations (gray dashed line).

groups, as P. littoralis is fixed in a different allele. All variance components are statistically significant.

\section{Other allozymes}

The number of studied individuals and allozyme allele frequencies for each population in the Guérande region is given in additional file 3 . In the Guérande and considering two groups (AMOVA; six $P$. chalceus populations (canals and ponds) versus three $P$. littoralis populations), the major part of variance (based on four neutral allozymes) is found between species (Table 3; 58.43\%). If we consider three groups (three canal populations $(P$. chalceus), three pond populations ( $P$. chalceus) and three $P$. littoralis populations, the variance among groups drops to $41.99 \%$ and the major part of variance is now found within populations (53.02\%). Variance among populations within groups considering three groups instead of two remains in the same range $3.39 \%$ for two groups compared to $4.98 \%$ for three groups).

The number of studied individuals and allozyme allele frequencies for each population at a European scale is given in additional file 4. At a European scale and considering two groups (AMOVA; 25 P. chalceus populations and six $P$. littoralis populations), the major part of variance (based on four neutral allozymes) is found within populations (Table $3 ; 49.81 \%$ ) and among groups (36.49\%). If we consider four ecological groups (14 temporary $(P$. chalceus), five intermediately stable ( $P$. chalceus), six highly stable ( $P$. chalceus) and six $P$. littoralis populations, the variance among groups drops to $19.05 \%$ and the major part of variance is still found within populations (65.24\%). Variance among populations within groups considering four groups instead of two remains in the same range 
Table 2: Analysis of variance (nested design ANOVA) based on male or female relative wing size in two regions: Guérande microscale and Europe macroscale

\begin{tabular}{|c|c|c|c|c|}
\hline & groups & source of variation & $\%$ var male & $\%$ var female \\
\hline \multirow[t]{6}{*}{ Guérande } & P. chalceus/P. littoralis & among groups & 78.84 & 80.37 \\
\hline & & among populations within groups & 18.64 & 16.21 \\
\hline & & within populations & 2.52 & 3.43 \\
\hline & ponds/canals/P. littoralis & among groups & 95.48 & 93.92 \\
\hline & & among populations within groups & 0.64 & 0.80 \\
\hline & & within populations & 3.88 & 5.58 \\
\hline \multirow[t]{6}{*}{ Europe } & P. chalceus/P. littoralis & among groups & 57.61 & 60.16 \\
\hline & & among populations within groups & 36.11 & 32.80 \\
\hline & & within populations & 6.28 & 7.05 \\
\hline & stable/intermediate/temporary/P. littoralis & among groups & 82.22 & 82.58 \\
\hline & & among populations within groups & 6.34 & 6.89 \\
\hline & & within populations & 11.45 & 10.54 \\
\hline
\end{tabular}

(13.70\% for two groups compared to $15.71 \%$ for four groups). All variance components are statistically significant.

\section{Mitochondrial DNA}

The 459-bp COI mitochondrial sequences revealed two haplotypes in the Guérande region. Haplotype one was shared by individuals of both canal and pond ecotype. Haplotype two was exclusive to the canal ecotype (Table 4 ). The 497-bp 16S sequences revealed only one haplotype in the Guérande region (Table 5).

The 459-bp COI sequences included 32 variable sites on a European scale (29 parsimony informative) and revealed nine unique haplotypes (four for $P$. chalceus and five for $P$. littoralis, with no haplotype shared by the two species). Most haplotypes were exclusive to a particular sampling site, with the exception of haplotype one and three which appeared in eight different localities, and haplotype five, which was found in three localities (Table 4). Selective neutrality was confirmed for this gene $(P>0.1$ for all test statistics with $D^{*}$ and $F^{*}$ ).

The neighbour joining tree in Figure 5 shows that both species form clearly separated entities (high bootstrap values). Differences are found in 28 positions between haplotypes 5,6,8,9 (P. littoralis) and haplotypes 1 and $2(P$. chalceus; Table 4). 27 base differences are found between haplotypes 5,6,8,9 and haplotypes 3 and 4 ( $P$. chalceus). 27 base differences are found between haplotype 7 ( $P$. littoralis) and haplotypes 1,2 (P. chalceus) and 26 base differences with haplotypes 3,4 ( $P$. chalceus). Intrapopulation differences in both $P$. chalceus and $P$. littoralis are very small (only a limited number of individuals studied) and between each haplotype there are only one to at most two bases different.

The 497-bp 16S sequences included 11 variable sites (9 parsimony informative) and revealed three unique haplotypes (Table 5; two for P. chalceus and one for P. littoralis,

Table 3: Analysis of molecular variance (AMOVA) based on IDHI allozyme or 4 neutral allozymes in two regions: Guérande microscale and Europe macroscale

\begin{tabular}{|c|c|c|c|c|}
\hline & groups & source of variation & $\% \operatorname{var} I D H I$ & $\%$ var allo \\
\hline \multirow[t]{6}{*}{ Guérande } & P. chalceus/P. littoralis & among groups & 61.93 & 58.43 \\
\hline & & among populations within groups & 11.49 & 3.39 \\
\hline & & within populations & 26.57 & 39.18 \\
\hline & ponds/canals/P. littoralis & among groups & 64.25 & 41.99 \\
\hline & & among populations within groups & 0.1 & 4.98 \\
\hline & & within populations & 35.65 & 53.02 \\
\hline \multirow[t]{6}{*}{ Europe } & P. chalceus/P. littoralis & among groups & 62.29 & 36.49 \\
\hline & & among populations within groups & 12.26 & 13.70 \\
\hline & & within populations & 25.44 & 49.81 \\
\hline & stable/intermediate/temporary/P. littoralis & among groups & 53.26 & 19.05 \\
\hline & & among populations within groups & 2.07 & $|5.7|$ \\
\hline & & within populations & 44.67 & 65.24 \\
\hline
\end{tabular}




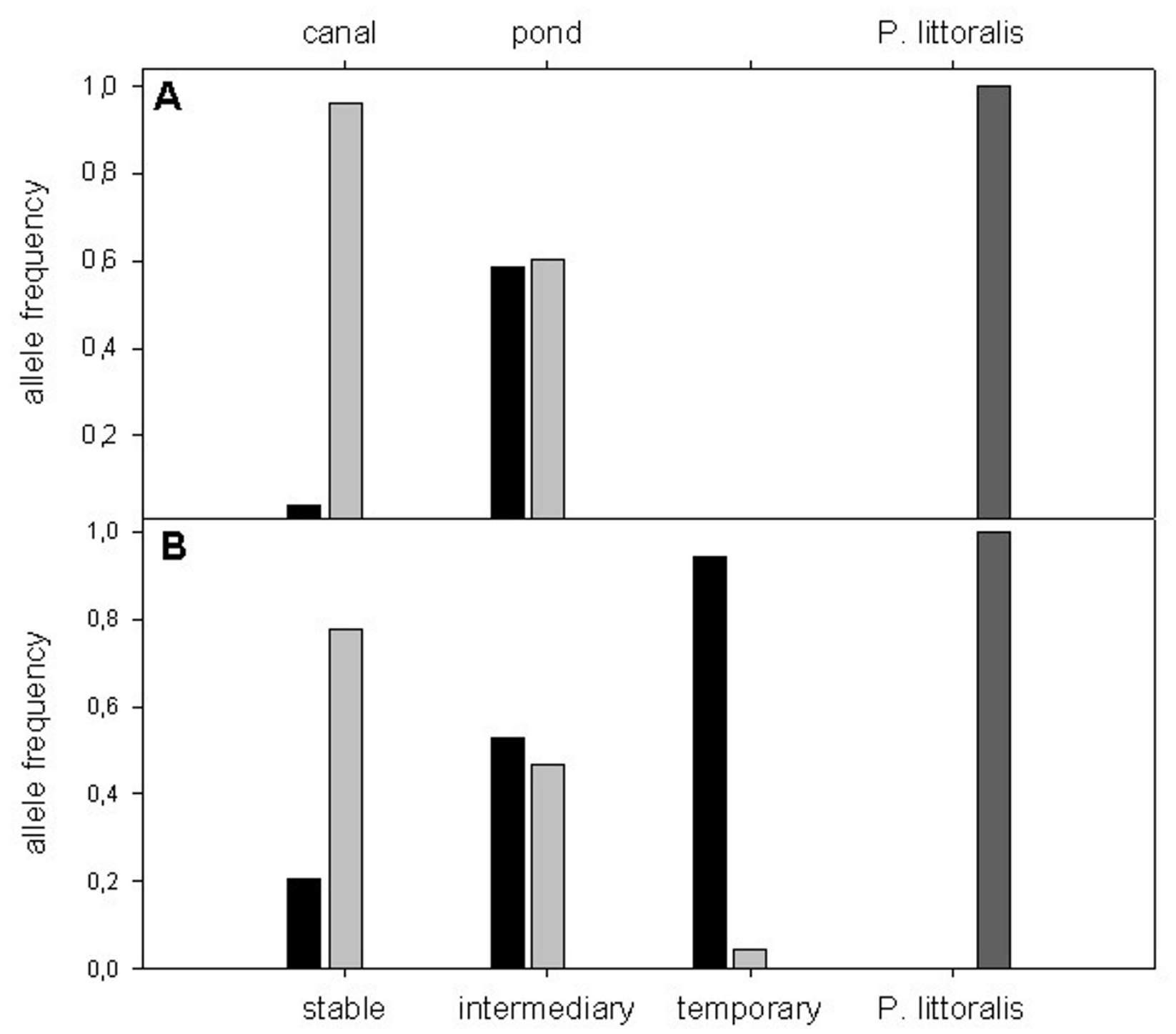

Figure 3

Allele frequencies for IDHI in the Guérande region (part $A$; cnals (P. chalceus) and ponds ( $P$. chalceus) and $P$. littoralis). Allele frequencies for IDHI on a European scale (part B; stable ( $P$. chalceus) and intermediate $(P$. chalceus), temporary and $P$. littoralis). Idh I-2: black, Idh I-4: light gray; Idh I-6: dark gray.

with no haplotype shared by the two species). Only one haplotype was exclusive to a particular sampling site (haplotype two). Haplotype one appeared in all $11 P$. chalceus localities, and haplotype three appeared in all three $P$. littoralis sites. Selective neutrality was confirmed for this gene $\left(P>0.1\right.$ for all test statistics with $D^{*}$ and $\left.F^{*}\right)$. Both species form, as in the case for COI, clearly separated entities (Table 5). 10 base differences are found between haplotype 3 (P. littoralis) and haplotypes 1 and 2 (P. chalceus). Interpopulation differences in both $P$. chalceus are very small (between the two haplotypes there is only one base different). There were no interpopulation differences found in P. littoralis.

\section{Discussion}

Pogonus littoralis and Pogonus chalceus are closely related species, sometimes relatively hard to identify without dissection of the genitalia. We are interested to study the evolutionary processes in and between these presumably young species. We therefore compare the degree of intraspecific variation (in ecological groups of $P$. chalceus) and the degree of interspecific variation $(P$. chalceus versus 


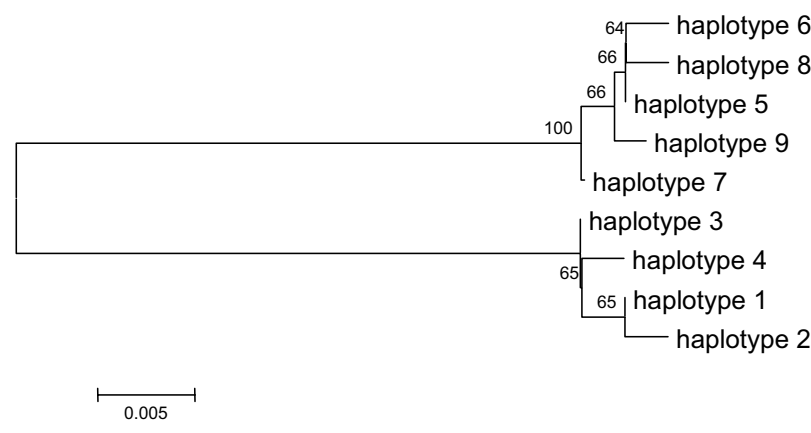

Figure 4

Neighbour joining tree based on $\mathrm{COI}$ haplotypes described in Table 2. Haplotype I-4 are found in P. chalceus and haplotype 5-9 in P. littoralis. Bootstrap values are indicated (1000 replicates).

P. littoralis) between a variety of morphological characteristics and molecular markers. In all of these cases, we did this with an ANOVA splitting up the total variance among groups, among populations within groups and within populations (Table 6).

At both geographical scales and considering two groups ( $P$. chalceus populations versus $P$. littoralis populations), a very large part of the total variance (based on body size, relative wing size, IDH1 and four neutral allozymes) is found between species (summary in Table 6). The study of the two mitochondrial genes also shows that both species form clearly separated entities. It is clear that relative wing size differences as well as genetic differences between the sister species $P$. chalceus and $P$. littoralis (interspecific) in this study are very marked and allow an easy species recognition.

Body size, relative wing size and IDH1 allozyme data in the beetle $P$. chalceus are also strongly divergent between contrasting microhabitats (intraspecific: two ecotypes in Guérande) as well as between three ecological groups at macroscale (highly stable versus intermediately stable and temporary populations; [2] and this study). If we consider four groups on a macroscale ( 3 groups in $P$. chalceus +1 group of $P$. littoralis) or three groups on a microscale (2 ecotypes in $P$. chalceus +1 group of $P$. littoralis), the variance among populations within groups drops drastically as compared to the analysis of two groups (all P. chalceus populations versus $P$. littoralis; based again on body size, relative wing size and IDH1; summary in Table 6). This study clearly shows that the intraspecific variation based on those three characteristics in $P$. chalceus is very high and in the same order of magnitude as the degree of interspecific variation ( $P$. chalceus versus $P$. littoralis). We have suggested earlier that this huge phenotypic and IDH1 divergence in $P$. chalceus has been driven by divergent natural selection [2]. As relative wing size is to a large extent genetically determined [1], this indeed suggests divergent selection between populations. And the observation that the IDH1 locus screened within our samples shows alelic differences between habitats strongly suggests a locus undergoing evolution through natural selection. Moreover, the canal and pond microhabitats differ from each other with respect to temperature, salinity and water level fluctuations [2]. Numerous studies based on allozymes have revealed patterns of allelic distribution associated with environmental factors, such as temperature and salinity $[13,14]$. Regarding the function of IDH1, the enzyme catalyses the rate-limiting step of the tricarboxylate cycle. Possible links with growth, however, are not direct and could be associated with the energy that is produced from the reaction. Divergent selection can lead to reproductive isolation and assortative mating and ultimately to speciation $[8,15]$.

On the other hand, in a previously study was shown that $P$. chalceus ecotypes in the Guérande region were only slightly differentiated (based on allozyme and microsatellite markers) compared to the results based on adaptive characteristics [2]. The smaller degree of intraspecific divergence is also reflected in the mitochondrial data from this study. Moreover, allozyme and mtDNA data from this study show that the populations of $P$. chalceus are much more related to each other than to their sister species $P$. littoralis both on a micro- and macroscale. Often, little or no genetic divergence is found in neutral markers between ecologically and morphologically differentiated populations $[3-5,7,16-18]$. Our results can be interpreted as a case of ongoing speciation in $P$. chalceus where divergence reflects a balance between selection and gene flow (see also [2]). Several studies suggest that tital marshes may be an appropriate ecotone in which to search for instances of ecological speciation. The studied species show, as is the case in our study, distinct morphological differences despite little divergence in molecular markers [7,19-21].

In view of the above shown analogy between intra- and interspecific variation, it seems reasonable to assume that the same ecological adaptive bifurcation was also the first step in the speciation process of $P$. chalceus and $P$. littoralis. The speciation process was here fully accomplished by the reproductive isolation between the two groups, allowing independent drift and mutation accumulation in neutral genetic characters.

\section{Methods \\ Sampling}

$P$. chalceus populations from three different sites in the Guérande region are analysed (microscale; Fig. 5; see also [2]). Each site consists of two drastically differing micro- 
\pm Table 4: 459 bp of COI sequenced for 90 individuals of $P$. chalceus and 22 of $P$. littoralis

GATTAGTTCCTTTAATATTxAGCACCxGATATAGCxTTTCCTCGAATAAATAATATAAGTTTTTGAxTATTACCTCCTTCxTTAACACTACTTTTAATAAGxAGx

ATGGTAGAAGAGG

TAGCAGG

TGTAGGAATTACTGCTTTACTTTTATTATTATCATTACCAGTTTTAGCTGGAGCA.

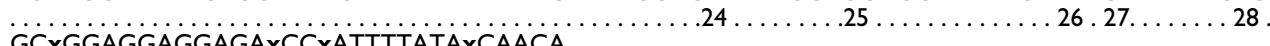

$.29 \ldots \ldots .30 \ldots 31 \ldots \ldots 32 \ldots$

Haplotype sequence information

\begin{tabular}{c} 
Haplotype No. \\
\hline \\
2 \\
3 \\
4 \\
5 \\
6 \\
7 \\
8 \\
9
\end{tabular}

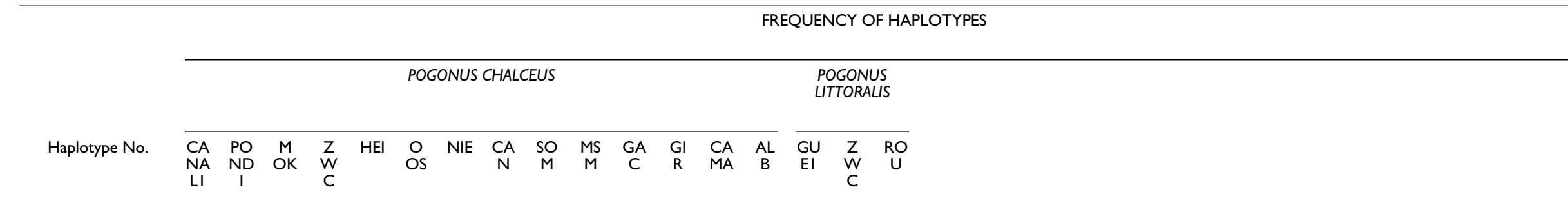

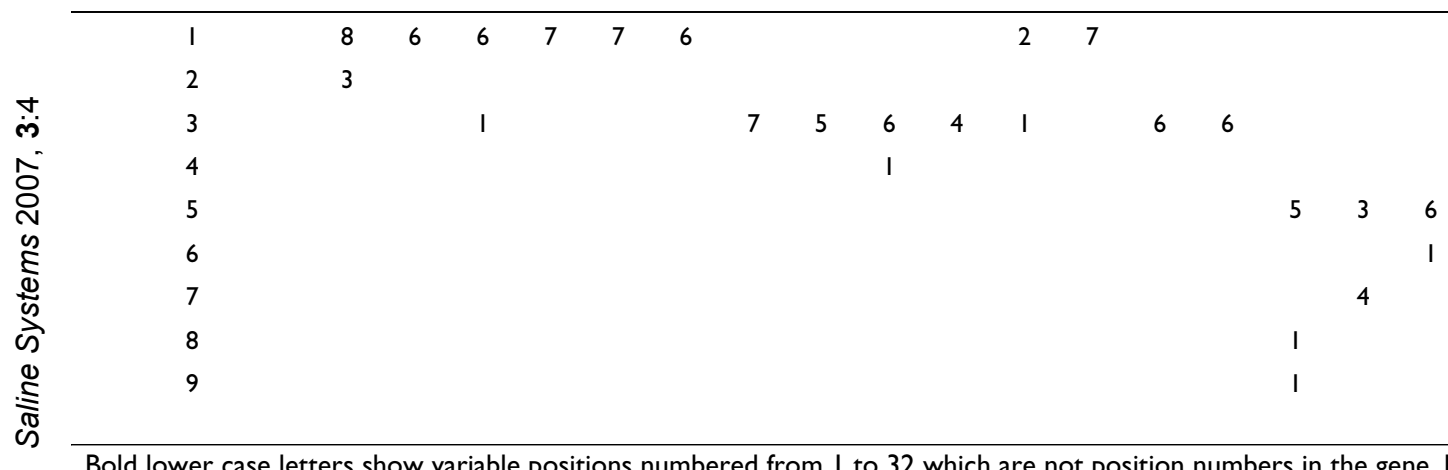

The table below shows the haplotype frequency in each population. 
Table 5: 497 bp of 165 sequenced for 62 individuals of $P$. chalceus and 15 of $P$. littoralis.

TTTATCAAAAACATGTCTTTTTGAGTTTAATATAAAGTCTAxCCTGCCCACTGAAAxTTTTAAATGGCCGCAGTAATTTGACTGTGCAAAGGTAGCATAATCT

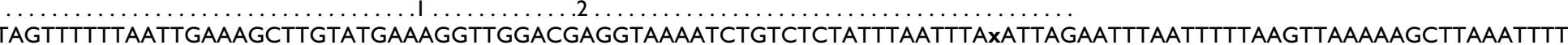
TAGTTTTTTAATTGAAAGCTTGTATGAAAGGTTGGACGAGGTAAAATCTGTCTCTATTTAATTTAXATTAGA

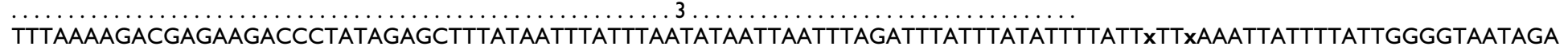

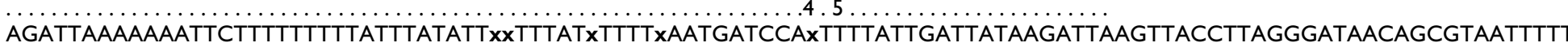
$\ldots \ldots \ldots \ldots \ldots \ldots \ldots \ldots .67 \ldots 89 \ldots 10 \ldots \ldots \ldots 11 \ldots \ldots \ldots \ldots \ldots \ldots \ldots \ldots \ldots \ldots \ldots \ldots$ TGGAGAGTTCAT ATCGATAAAAAAGTTTGCGACCTCGATGTTGGATTAAAGATTAGTTTAGGTGTAGAAGTTTAAA

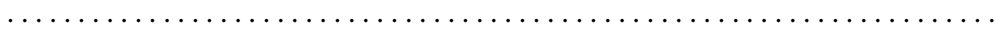

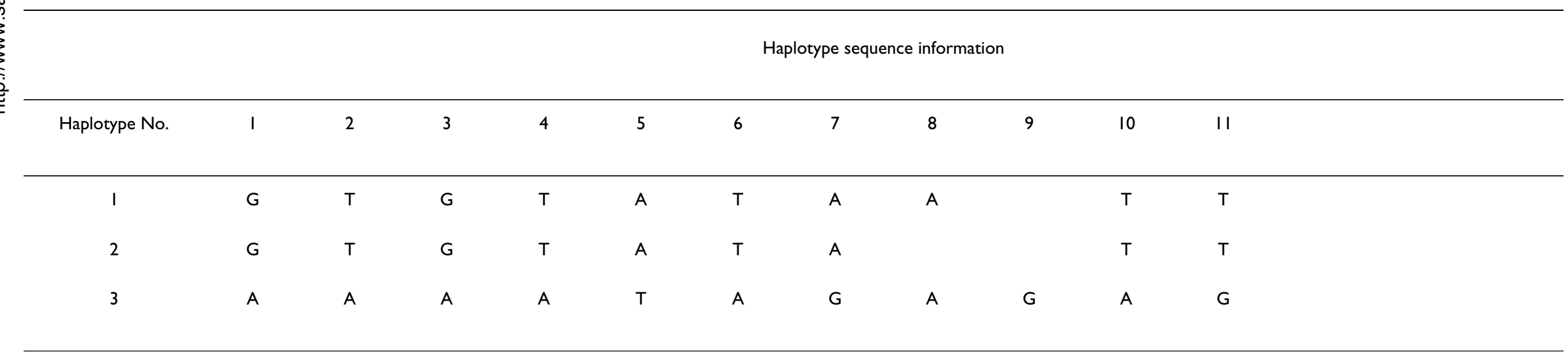

Frequency of haplotypes

\section{POGONUS CHALCEUS}

\begin{tabular}{|c|c|c|c|c|c|c|c|c|c|c|c|c|c|c|}
\hline Haplotype No. & CANALI & PONDI & MOK & ZWC & $\mathrm{HEI}$ & OOS & NIE & SOM & MSM & CAMA & ALB & GUEI & ZWC & ROU \\
\hline I & 6 & 6 & 5 & 6 & 7 & 4 & 5 & 5 & 7 & 5 & 5 & & & \\
\hline 2 & & & & I & & & & & & & & & & \\
\hline 3 & & & & & & & & & & & & 6 & 5 & 4 \\
\hline
\end{tabular}




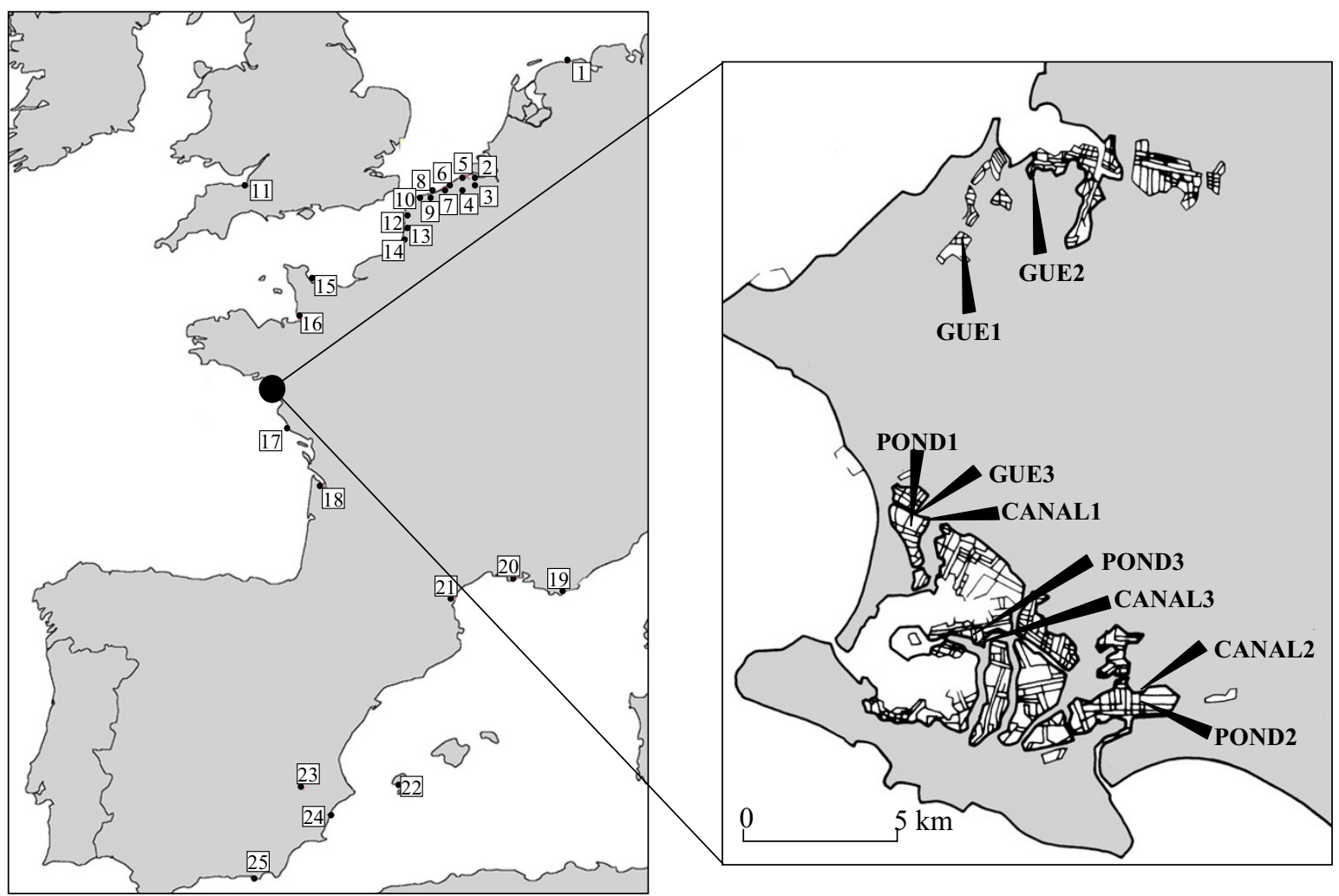

\section{Figure 5}

Geographical distribution of the studied populations of Pogonus chalceus and Pogonus littoralis. The following population codes were used: I:FRI; 2:BRA; 3:WAT; 4:MOK; 5:ZWC; 6:HEI; 7:LIS; 8:OOS; 9:NIE; I0:MOE; II:SEA; I2:CAN;

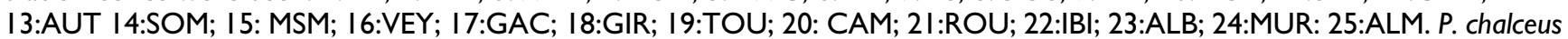
populations were sampled from all indicated numbers (I-25). P. littoralis were sampled in the populations with number 5, I3, I5, 19, 20 and 2I. The detailed map is the Guérande region containing three studied $P$. chalceus pond populations (PONDI, POND2, POND3), three $P$. chalceus canal populations (CANALI, CANAL2, CANAL3) and three $P$. littoralis populations (GUEI, GUE2, GUE3).

habitats, situated only 10-20 metres from each other and separated by one or two dikes. We compare P. chalceus populations from three canals (CANAL1; CANAL2; CANAL3: Fig. 5) to three adjacent pond populations (POND1; POND2, POND3; see also [2]). Furthermore, we analyse Guérande $P$. littoralis populations from three different sites (GUE1, GUE2, GUE3; Fig. 5; see also [12]) nearby the aforementioned $P$. chalceus population couples.

The two related species are also studied on a macroscale with completely independent population samples (Guérande populations not included). Data on P. chalceus populations from the Netherlands (FRI), Belgium (BRA, WAT, MOK, ZWC, HEI, LIS, OOS, NIE, MOE), England (SEA), France (CAN, AUT, SOM, MSM, VEY, GAC, GIR, TOU, CAM, ROU), and Spain (IBI, ALB, MUR, ALM; Fig. 5 ; see also $[11,22]$. For $P$. littoralis, six populations are analysed here, five of them from France (AUT, MSM, TOU, CAM, ROU; [12]). From these sites in France, we also sampled $P$. chalceus populations (see above). In Belgium, $P$. littoralis is critically endangered and the previous record went back to 1956 and was from Ostend [23]. Recently, a supposed new $P$. littoralis population has been discovered in Belgium and is also included here (Fig. 5; ZWC). Populations of $P$. chalceus on a European scale were assigned 
Table 6: Summary of analysis of variance for body size, wing size, IDHI and allozymes

\begin{tabular}{|c|c|c|c|c|c|}
\hline region & source of variation & $\%$ var body size male & $\%$ var wing size male & $\% \operatorname{var} I D H I$ & $\%$ var allo \\
\hline \multirow[t]{3}{*}{ Guérande } & among groups ( $P$. chalceus vs $P$. littoralis) & 74.24 & 78.84 & 61.93 & 58.43 \\
\hline & among populations within groups & 17.50 & 18.64 & 11.49 & 3.39 \\
\hline & within populations & 8.26 & 2.52 & 26.57 & 39.18 \\
\hline \multirow[t]{3}{*}{ Europe } & among groups ( $P$. chalceus vs $P$. littoralis) & 68.37 & 57.61 & 62.29 & 36.49 \\
\hline & among populations within groups & 10.13 & 36.11 & 12.26 & 13.70 \\
\hline & within populations & 21.51 & 6.28 & 25.44 & 49.81 \\
\hline \multirow[t]{3}{*}{ Guérande } & among groups ( 2 ecotypes vs $P$. littoralis) & 84.96 & 95.48 & 64.25 & 41.99 \\
\hline & among populations within groups & 2.35 & 0.64 & 0.1 & 4.98 \\
\hline & within populations & 12.69 & 3.88 & 35.65 & 53.02 \\
\hline \multirow[t]{3}{*}{ Europe } & among groups ( 3 ecolog groups vs $P$. littoralis) & 49.39 & 82.22 & 53.26 & 19.05 \\
\hline & among populations within groups & 5 & 6.34 & 2.07 & $|5.7|$ \\
\hline & within populations & 45.62 & 11.45 & 44.67 & 65.24 \\
\hline
\end{tabular}

to belong to one of three different salt marsh area stability types: temporary (BRA, WAT, MOK, HEI, LIS, OOS, MOE, TOU, CAM, ROU, IBI, ALB, MUR, ALM), intermediate (ZWC, NIE, MSM, FRI, AUT) and stable (SEA, CAN, SOM, VEY, GAC, GIR; see also [2,11]. Temporary populations of $P$. chalceus are situated in the Mediterranean part of Europe or occur in small ( $<4 \mathrm{ha})$ and young ( $<400$ years) Atlantic salt marshes. Stable and intermediate populations live in larger marshes situated along the Atlantic coast. The only difference between both salt marsh areas is their estimated age (Stable: $>1000$ years; Intermediate: between 400-1000 years). The age of salt marshes was estimated using historical information [24-27].

\section{Morphological analysis}

Body size (elytral length) and wing size were measured by means of a calibrated ocular under a binocular microscope. Generally, carabid wing size follows an allometric relationship with body size. [28] developed an index that corrects for this allometry, i.e. percentage of maximal realisable relative wing size. Relative wing size is wing length $x$ width divided by elytral length $\times$ width. Relative wing size is then expressed as a percentage of the maximal wing size for a beetle of a given size. This index was shown to be an unbiased estimator for comparing different individuals, populations and species of carabid beetles [28]. In ground beetles, females are generally larger than males. Therefore, we analyse male and female body sizes separately. To be complete, we analyse female and male relative wing size also separately. Body size and relative wing size are compared between species and populations with ANOVA's. Total variance is partitioned among groups (species or species and ecotypes), among populations within groups, and within populations by carrying out a nested design ANOVA using STATISTICA (version 7.1; StatSoft Inc., Tulsa, UK) on both a micro- and macroscale.

\section{Genetic divergence}

Data are used from five polymorphic enzymes: aldehyde oxidase (AO, E.C. 1.2.3.1), glucose-6-phosphate isomerase (GPI, E.C. 5.3.1.9), isocitrate dehydrogenase 1 and 2 (IDH1, IDH2, E.C. 1.1.1.42), phosphoglucomutase (PGM, E.C. 2.7.5.1.). Protocols of electrophoresis are provided by [29]. Earlier work showed that one locus (IDH1) was non-neutral and we will always analyse it separately [11].

Departures from Hardy-Weinberg equilibrium expectation were tested with an exact test using the GENEPOP software (Version 3.2; [30]). Significance levels were adjusted by using sequential Bonferroni correction. Similarly as in the analyses for body and wing size, total genetic variance is partitioned among groups (species, ecotypes), among populations within groups, and within populations by carrying out a hierarchical analysis of molecular variance (AMOVA) using ARLEQUIN (version 3.000 ; [31]) on both a micro- and macroscale.

PCRs for nucleotide sequencing of COI utilized primers C1-J-1718 and C1-N-2191 and for 16S we utilized primers LR-J-1307 and LR-N-13398 [32]. DNA amplification reactions were performed in a $25 \mu \mathrm{L}$ final volume. Each reaction mix contained $5 \mu \mathrm{L}$ of extract, $1 \times$ buffer (Sigma), $1.5 \mathrm{mM} \mathrm{MgCl}_{2}, 200 \mu \mathrm{M}$ of each dNTP, $0.4 \mu \mathrm{M}$ of each primer and 0.6 U RedTaq DNA polymerase (Sigma). Initial denaturation was for $2 \mathrm{~min}$ at $95^{\circ} \mathrm{C}$, followed by 35 cycles of $1 \mathrm{~min}$ at $95^{\circ} \mathrm{C}, 1 \mathrm{~min} 30 \mathrm{~s}$ at $48^{\circ} \mathrm{C}$ (and $46^{\circ} \mathrm{C}$ for $16 \mathrm{~S}$ ), and $2 \mathrm{~min}$ at $72^{\circ} \mathrm{C} ; 9 \mathrm{~min}$ at $72^{\circ} \mathrm{C}$ completed the program. The reaction was purified with columns following manufacturer's recommendations. Sequencing was done by BigDye Terminator version 3.1 kits on an ABI 3130 sequencer (Applied Biosystems). Sequences were aligned using BioEdit version 5.0.6 [33]. We tested for 
neutrality of mutations following Fu \& Li's method with $D^{*}$ and $F^{*}$ test statistics using DNASP $4.0[34,35]$. A phylogeny of unique haplotypes was constructed from the calculated Kimura two-parameter distances using the neighbour-joining approach within MEGA ([36]; 1000 bootstrap replicates).

\section{Competing interests}

The author(s) declare that they have no competing interests.

\section{Authors' contributions}

HD collected the majority of the data, and carried out most of the calculations and drafted the text. Y-PM assisted the field work, advised regarding ANOVA's and final edited the text. KD supplied historical information, assisted the field work and advised on all used methods and final edited the text. All three authors read and approved the final text.

\section{Additional material}

\section{Additional file 1}

Number of males and females for which body size and wing size is measured and number of individuals used for IDH1 allozyme electrophoresis in the Guérande populations.

Click here for file

[http://www.biomedcentral.com/content/supplementary/17461448-3-4-S1.doc]

\section{Additional file 2}

Number of males and females for which body size and wing size is measured and number of individuals used for IDH1 allozyme electrophoresis in the different populations on a European scale.

Click here for file

[http://www.biomedcentral.com/content/supplementary/1746-

1448-3-4-S2.doc]

\section{Additional file 3}

Allele frequencies from four allozymes (AO, IDH2, PGI, PGM) studied in the Guérande populations. N: number of studied individuals.

Click here for file

[http://www.biomedcentral.com/content/supplementary/17461448-3-4-S3.doc]

\section{Additional file 4}

Allele frequencies from four allozymes (AO, IDH2, PGI, PGM) studied in the European populations. N: number of studied individuals.

Click here for file

[http://www.biomedcentral.com/content/supplementary/17461448-3-4-S4.doc]

\section{Acknowledgements}

This work was supported by the Entomology Department of the Royal Belgian Institute of Natural Sciences and OSTC project MO 36/006. It is carried out within the framework of the Flemish Research Network
(FWO.017.02N, 'Ecological genetics: a new approach'). A. Drumont assisted with part of the laboratory work.

\section{References}

I. Desender K: Heritability and wing development and body size in a carabid beetle, Pogonus chalceus MARSHAM, and its evolutionary significance. Oecologia 1989, 78:5।3-520.

2. Dhuyvetter H, Hendrickx F, Gaublomme E, Desender K: Differentiation between two salt marsh beetle ecotypes: evidence for ongoing speciation. Evolution 2007, 61:184-193.

3. Schneider C), Smith TB, Larison B, Moritz C: A test of alternative models of diversification in tropical rainforests: ecological gradients vs. rainforest refugia. PNAS 1999, 96:13869-13873.

4. Ogden R, Thorpe RS: Molecular evidence for ecological speciation in tropical habitats. PNAS 2002, 99:13612-13615.

5. Saint-Laurent $R$, Legault $M$, Bernatchez $L$ : Divergent selection maintains adaptive differentiation despite high gene flow between sympatric rainbow smelt ecotypes (Osmerus mordax Mitchill). Mol Ecol 2003, I 2:3 I5-330.

6. Nosil P, Crespi BJ: Does gene flow constrain adaptive divergence or vice versa? A test using ecomorphology and sexual isolation in Timema cristinae walking-sticks. Evolution 2004, 58:102-II2.

7. Grenier JL, Greenberg R: A biogeographic pattern in sparrow bill morphology: parallel adaptation to tidal marshes. Evolution 2005, 59:1588-1595.

8. Schluter D: Ecology and the origen of species. TREE 200I, 16:372-380

9. Coyne JA, Orr HA: Speciation Sinauer Associates, Inc., Sunderland, MA; 2004.

10. Desender K: Dispersievermogen en ecologie van loopkevers (Coleoptera, Carabidae) in België: een evolutionaire benadering Studiedocumenten van het KBIN, Brussels; 1989.

II. Dhuyvetter H, Gaublomme E, Desender K: Genetic differentiation and local adaptation in the salt-marsh beetle Pogonus chalceus: a comparison between allozyme and microsatellite loci. Mol Ecol 2004, I3: I065-1074.

12. Dhuyvetter H, Gaublomme E, Verdyck P, Desender K: Genetic differentiation among populations of the salt marsh beetle Pogonus littoralis (Coleoptera: Carabidae): A comparison between Atlantic and Mediterranean populations. I Heredity 2005, 96:38I-387.

13. Mitton JB: Selection in natural populations. Oxford Univ. Press, New York.

14. Eanes WF: Analysis of selection on enzyme polymorphism. Annu Rev Ecol Syst 1999, 30:301-326.

15. Rundle HD, Nosil P: Ecological speciation. Ecology letters 2005, 8:336-353.

16. Orr MR, Smith TB: Ecology and speciation. Trends Ecol Evol 1998, 13:502-506.

17. Piertney SB, Summers R, Marquiss M: Microsatellite and mitochondrial DNA homogeneity among phenotypically diverse crossbill taxa in the UK. Proc R Soc Lond B 200I, 268:15II-I5I7.

18. Jordan MA, Snell HL, Snell HM, Jordan WC: Phenotypic divergence despite high levels of gene flow in Galápagos lava lizards (Microlophus albemarlensis). Mol Ecol 2005, I 4:859-867.

19. Beheregaray LB, Sunnucks P: Fine-scale genetic structure, estuarine colonization incipient speciation in the marine silverside fish Odontesthes argentinensis. Mol Ecol 200 I, 1 0:2849-2866.

20. Brown AF, Kann LM, Rand DM: Gene flow versus local adaptation in the northern acorn barnacle, Semibalanus balanoides: insights from mitochondrial DNA variation. Evolution 200I, 55: 1972-1979.

21. Chan Y, Arcrese P: Subspecific differentiation and conservation of song sparrows (Melospiza melodia) in San Francisco Bay region inferred by microsatellite loci analysis. Auk 2003 , I | 9:64|-657.

22. Dhuyvetter H, Gaublomme E, Desender K: Bottlenecks, drift and differentiation: the fragmented population structure of the saltmarsh beetle Pogonus chalceus. Genetica 2005, I 24: 167-177.

23. Desender K, Maes D, Maelfait J-P, Van Kerckvoorde M: Een gedocumenteerde Rode lijst van de zandloopkevers en loopkevers van Vlaanderen Mededelingen van het instituut voor natuurbehoud, Brussels; 1995. 
24. Desender K: Wing polymorphism and reproductive biology in the halobiont carabid beetle Pogonus chalceus (Marsham) (Coleoptera, Carabidae). Biol Jb Dodonaea 1985, 53:89-100.

25. Goetghebeur P: De vegetatie van de slikken en de schorren langs de ljzermonding te Nieuwpoort (Prov. West-Vlaandere, België) van 1900 tot heden. Biol Jb Dodonaea 1976, 44:163-177.

26. Hoffmann M: The vegetation of the Westgeul (Terneuzen, Netherlands). Biol Jb Dodonaea 1986, 54:I6I-I73.

27. Houthuys R, De Moor G, Sommé J: The shaping of the FrenchBelgian North Sea coast throughout recent geology and history. In Coastlines of the South North Sea Edited by: Hillen R, Verhagen HJ. American Society of Civil Engineers; 1993.

28. Desender K, Maelfait J-P, Vaneechoutte M: Allometry and evolution of hind wing development in macropterous carabid beetles. In Carabid beetles: Their adaptations and dynamics Edited by: Den Boer PJ, Luff M, Mossakowski D, Weber F. Stuttgart, Gustav Fisher; 1986:101-112.

29. Desender K, Backeljau T, Delahaye K, De Meester L: Age and size of European saltmarshes and the population genetic consequences for ground beetles. Oecologia 1998, I I 4:503-5 I 3.

30. Raymond M, Rousset F: GENEPOP (Version I.2): population genetics software for exact tests and ecumenicism. I Hered 1995, 86:248-249.

31. Schneider S, Roessli D, Excoffier L: ARLEQUIN version 3.000: a software for population genetics data analysis. Anthropology: University of Genève; 2000.

32. Simon C, Frati F, Beckenbach A, Crespi B, Liu H, Flook P: Evolution, weighting, and phylogenetic utility of mitochondrial gene sequences and a compilation of conserved polymerase chain reaction primers. Ann Entomol Soc Amer 1994, 87:65 I-70I.

33. Hall AT: BioEdit: a user-friendly biological sequence alignment, editor and analysis program for Windows 95/98/NT. Nucleic Acids Symposium Series 1999, 41:95-98.

34. Fu YX, Li WH: Statistical tests of neutrality of mutations. Genetics 1993, 133:693-709.

35. Rozas J, Sanchez-De I, Barrio JC, Messeguer X, Rozas R: DNASP, DNA polymorphism analyses by the coalescent and ohter methods. Bioinformatics 2003, 19:2496-2497.

36. Kumar S, Tamura K, Nei M: MEGA: molecular evolutionary genetic analysis, v. I.0 I. University Parkt, PA 16802: The Pennsylvania State University.
Publish with Bio Med Central and every scientist can read your work free of charge

"BioMed Central will be the most significant development for disseminating the results of biomedical research in our lifetime. "

Sir Paul Nurse, Cancer Research UK

Your research papers will be:

- available free of charge to the entire biomedical community

- peer reviewed and published immediately upon acceptance

- cited in PubMed and archived on PubMed Central

- yours - you keep the copyright
BioMedcentral 